\title{
EXPLORATION OF BANDUNG THROUGH ANHOLT HEXAGONAL CITY BRAND SUSTAINED BY CORN AGRIBUSINESS IN ARJASARI DISTRICT
}

\author{
Beryl Gandakusumah* and Rustono Farady Marta \\ Communication Science, Graduate School Program, Universitas Bunda Mulia, Jakarta Utara, Indonesia \\ Correspondence Email: berylisme@gmail.com, rmarta@bundamulia.ac.id
}

Submitted 06 April 2020; Accepted 14 October 2020

\begin{abstract}
ABSTRAK
Jawa Barat sebagai provinsi dengan jumlah penduduk terbesar yang membawahi banyak kota, salah satunya Bandung seyogianya dapat memberikan kontribusi pada perekonomian Indonesia melalui pengembangan aspek citra sebuah kota yang juga dapat disebut dengan city brand. Penelitian ini akan melihat komponen pembentuk Bandung, khususnya kawasan Arjasari yang belum maksimal dan dapat ditingkatkan, sehingga tercipta perkembangan ekonomi kreatif yang baik pada kawasan Arjasari dan secara sosial ekonomi dapat bernilai positif bagi masyarakat Arjasari dan bangsa Indonesia. Penelitian dilakukan dengan pendekatan kualitatif melalui observasi yang dianalisa dengan komponen hexagonal city brand yang diperkuat dengan data studi pustaka. Melalui strategi kompetitif degan mengembangkan berbagai aspek pembentuk sebuah daerah, maka Kawasan Arjasari dapat menjadi daerah yang maju secara sosial ekonomi melalui hasil pertanian yang berupa jagung.
\end{abstract}

Kata kunci: citra kota, ekonomi, hexagonal city brand, jagung, pemasaran, pertanian, strategi

\begin{abstract}
West Java as a province with the largest population that oversees many cities, one of which is that Bandung should be able to contribute to the Indonesian economy through the development of aspects of the image of a city which can also be called a city brand. This research will look at the forming components of Bandung, especially the Arjasari region which has not been maximized and can be improved, so as to create a good creative economic development in the Arjasari region and can be socially economically positive for the Arjasari community and the Indonesian people. The research was carried out with a qualitative approach through observations that are analyzed with hexagonal city brand components which are reinforced with literature study data. Through competitive strategies by developing various aspects of forming an area, the Arjasari Region can become a socially advanced region through agricultural products in the form of corn.
\end{abstract}

Keywords: city brand, corn, economy, farmer, hexagonal, marketing, strategy

\section{INTRODUCTION}

Indonesia that has 34 provinces is a big country that had about 255.461.711 citizens. In its classification as a province, West Java is in first place in terms of population number. As a city that is in second place in the population ranking in West Java province, Bandung also contributes significantly to the regional income of West Java Province. Based on data from the 2016
West Java Central Statistics Agency, Bandung Regency had 3,534,111 citizens. From the number of population, Bandung Regency can develop creative economic potential as a contribution to the national economy.

Image association can be understood that, if in an advertisement or image product can be defined as one of the components that affect a consumer's assessment of the product (Fensi and Christian, 2018), then success in applying an image to a city can also be 
considered to be a brand of a city that Simon Anholt called as a city brand (Sukmadewi and Novel, 2019). There are many aspects that can be explored from a city brand, starting from people, pulse, potential, prerequisites, present and place. Each aspect is a description or essence of the image of a city or regency, that very diverse. The balance of the achievements of each aspect will affect the image ranking value of a city or regency. It is a success if the government of a regency can carefully see the potential and support components in its area to be developed. Advances in information and communication technology can lead to the viewpoint of Bandung tourists by only seeing Bandung from aspects that are widely exposed by social media and internet. In fact, there are many other very worthy aspects to be taken into account and developed by the local government. If media exposure only focuses on one aspect, how can prospective Bandung tourists understand what other potentials exist in the area? The role played by Bandung is also inseparable from the satellite area around it. Arjasari Village, as one of the districts in Bandung Regency, is an agricultural area. It is unconsciously very developed and has an increase in need significantly.

Agriculture as an important factor in national economy is types of businesses that are spread in Indonesia as an agricultural country. Various types of plants in agriculture are also important commodities to fulfill food needs and it open up many jobs for Indonesians who have not fully qualified for education. Agricultural products for the Indonesian population are a basic need that must be fulfilled on a daily basis. In addition, the types of agricultural crops used daily also have other functions or forms that can be processed and developed by local farmers and entrepreneurs. The increasing need for agricultural crops continues to increase. Therefore, efforts to develop the agricultural sector as a business sector are great opportunities that are still less attractive to most people. There are various types of agricultural crops commonly planted by farmers in a village, such as from rice, maize/corn, sweet potatoes, and vegetables as well as fruits. As one of the main commodities that is also a strategic component in developing the national economy through agricultural development, corn had increased by $6.31 \%$ in the 2006 2015 period (Wahyuningsih, et al., 2018). Of several agricultural products that are Indonesia's export commodities, corn has become one of the commodities that has increased in production and become the government's focus in exports (Revania, 2013). The increase in corn exports every year opens up great opportunities for agribusiness in this sector. The increase in the number of national corn exports indicates that domestic maize needs have been met, yet, the export-import policy is still enforced to maintain stability and bilateral relations between countries.

One of the corn producers area in Bandung Regency is Arjasari Village. It has 768,848 hectare area with agricultural products in the form of sweet corn. The village can produce up to 1.5 tons of maize/corn per hectare. Due to the large number of wholesalers who provide cheap prices for a kilo of corn, maize/corn farmers in the Arjasari area must innovate from the abundant processed maize products (Djali et al., 2018). This can increase the selling value resulting in an increase in income for corn farmers in the area. Corn processing can be used in various other forms such as corn flour, corn milk, ice cream made from corn, light snacks, noodles made from corn, and chips that are usually made from melinjo can be replaced with corn. The ability and development of the number of corn harvested opens opportunities to advance the economy of the local population and to create creativity for processed products made from corn in Arjasari Village.

The daily activity of Anjasari villagers as corn farmers will of course result special ability and skills in processing maize/corn to produce good varieties and have high selling value. This is also a great opportunity for 
Arjasari Village to develop the area as an agricultural education tourism area. Agricultural education is an effort to provide theoretical explanations in real terms of processes in the world of agriculture, especially corn plants. The lack of media access and exposure to the area has made the area a second place. It is expected that the discussion of the research aspects of corn farmers can bring to light that the potential of corn farming in the Arjasari area is one of the core elements in the city image index through the exploration of the hexagonal city brand components that affect the performance of a region and make a positive contribution to the trade climate and the Indonesian economy.

This research aims to see that the potential progress of a city can also be achieved by paying attention to the city branding component that specifically focuses on the potential of an area. This potential can also be generated from corn agriculture, that so far may only have been considered a commodity value. In fact, it can open up the creative economy sector in the Arjasari District. The improvement of the socioeconomic conditions of the people in the area can also be improved and Arjasari Village can become an area that is economically independent, productive, and able to compete.

\section{RESEARCH METHOD}

This paper will focus of classification of supporting aspects of Bandung that have not been clearly described. As the bias in supporting aspects, investors and local communities can't apply the strength of agribusiness from Bandung that unconsciously actually benefits the development of the Indonesian economy. This research was viewed constructively with the construct of aspects that underlie the city brand index that underlies the image of a city, using a qualitative descriptive approach. The research object in this research focused on the aspects of the city brand of Bandung city with the research subject of the Arjasari community as corn farmers. The primary data of this research were the results of observations with the Arjasari Village apparatus. Mr. Dais, the secretary of Arjasari Village was chosen to be informant for this study. Then the data were analyzed with the components forming the image of a city, supported by the Arjasari population data as secondary data that were arranged together. The data obtained was an analysis of the exploration of the components of the Hexagon city brand (people, pulse, potential, prerequisite, presence, and place), and it was strengthened by documentation studies that could consist of scientific studies, theories, articles, notes, and other documentation models. This research examined how the position of the image of Bandung through the Simon Anholt city brand components and how each aspect is described in Bandung, especially the Arjasari area. Furthermore, it would be seen from the data obtained regarding agricultural products and the potential that existed in the area from tracing secondary data which can affect the competitive strategy for the development and progress of Bandung. They will indirectly move the wheels of the West Java economy and the Indonesian economy.

\section{RESULT AND DISCUSSION}

\section{Village Community Toward Corn Agricultural Products}

Dais as village secretary of Arjasari understood well the condition and demographics of the Arjasari Village community. As a village official, Mr. Dais served as a liaison between the Village Head and the community/villagers, as well as as the organizer and implementer of the social system in Arjasari Village. Based on the information obtained, Arjasari Village has the main agricultural products in the form of $70 \%$ sweet corn and $30 \%$ fresh corn.

Arjasari farmers tended to choose to get money quickly even though it was sometimes resulted with very minimal profits. The government also depended on the dealer or cukong buying corn in bulk at a price they 
set themselves because the dealer had provided assistance in the form of seeds, fertilizers and medicinal plants. The lack of publicity is one of the reasons why they could not sell their crops in the form of corn directly to several distributors. It actually created competitive price. Allocation of assistance from the local government was limited to seeds for fresh corn. The public mindset was not yet open to the processed corn that could be reduced to various types of products.

\section{City Brand}

The measurement index for a city brand is related to the aspects of tourism and culture that are the measuring points of the successful management of a city by the local government. The aspect of assessing the image of a city tends to be simpler than the assessment of a country. If the assessment of the value of a country depends on climate, culture, society, and infrastructure, with a smaller scope, a city can be assessed more objectively and simply on practical matters such as pollution, transportation, cost of living, sports and recreation, enforcement law and cultural life that takes place in a city. Even in the political aspect of a city, it is not as thick as the politics seen in the assessment of a country because there are boundaries between people's thinking in the actions taken by the government and cities in a country. City brand can also be used as a strategy by the government to provide an overview and shape perceptions about a place (Alperyte \& Išoraitè, 2020).

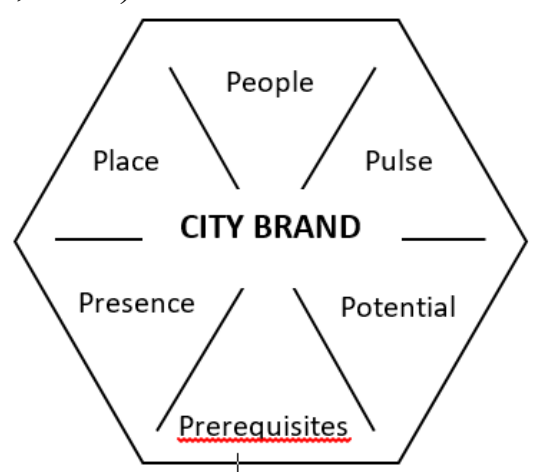

Figure 1. Hexagon City Brand Index Source: Simon Anholt's City Brand Index analysis in Luthfi and Widyaningrat (2013)
There are six aspects that can be used as benchmarks for a city brand. It can also be called City Brands Hexagon (Yurisma et al., 2015) that consists of:

\section{People}

Bandung that is well-known with its hospitality absolutely has a special attraction for tourists to have the experience of traveling or even living in Bandung. The friendliness of local residents in a place will affect the impression that newcomers get. This impression is very important to be considered that the diversity of cultural cultures through tourist visits in the Bandung area makes a different benchmark between assessors of the response of local people among touriss (Utama, 2016). If the hospitality aspect is owned, an area will tend to be considered positive because it is open and it welcomes existing migrants. Besides its hospitality, Bandung is also known as a creative city, where there are many murals or wall paintings and art installations in Bandung. With a high capital of creativity and artistic spirit, a city will be able to design creative strategies and apply the superior components of the city effectively and optimally. Hospitality that has become a soul of the people of Bandung can certainly be found in residents who live in the satellite area of the city of Bandung. It is the driving aspect of the pulse of the city of Bandung. Arjasari Village is located in the south of Bandung Regency. In 2019, the population was recorded at 10,927 people with 9,025 people of productive working age.

Based on information obtained from a site of Arjasari Village, the biggest obstacle of this village is an inequality of job availability to the number of productive worker. With the population in the unemployed category, the management structure of Arjasari Village has a vision to project Arjasari as a tourist destination village to be able to reduce unemployment and maximize the community as residents who have a positive, independent, and competitive economic structure. 
Table 1. Arjasari Village Community Workforce

\begin{tabular}{clr}
\hline No & \multicolumn{1}{c}{ Workforce } & Total \\
\hline 1 & Not completed in primary school & 83 \\
2 & Still in elementary school & 1.218 \\
3 & Graduated from elementary school & 660 \\
4 & Not completed in junior high school & 159 \\
5 & Still in junior high school & 5.325 \\
6 & Graduated from junior high school & 645 \\
7 & Still in senior high school & 367 \\
8 & Graduated from senior high school & 398 \\
9 & Still in college & 72 \\
10 & Graduated from college & 98 \\
\hline & Total & $\mathbf{9 . 0 2 5}$ \\
\hline
\end{tabular}

Source: Secondary Data (Processed)

With an educational background that is not yet optimal, farmers in Arjasari Village must be bridged by the local government to be able to build a business relationship between farmers and companies that need corn stocks mutually. Thus, the survival of farmers in Arjasari Village can be guaranteed because there is a good partnership between both parties (Azmie et al., 2017). Researchers see that the level of education in Arjasari Village has not been yet optimal due to the lack of creativity and fighting power they do in processing corn products. If education can be maximized, added with experiences that can't be measured by value, as well as knowledge and skills that are acquired by nature as farmers in their daily lives, farmers in Arjasari Village will be motivated to

become better in the aspects of behavior as a positive effect of knowledge about functions from something experienced by an individual (Fadhilah et al., 2018).

\section{Pulse}

Bandung has an attraction for tourists because Bandung is well known as a city that has historical buildings. The strength of Bandung are not only its hospitality aspect and strategic location, but also in the spirit transmitted through the activities that visitors can do. It includes from the center of culinary tourism, shopping, museums, nature tourism, to agriculture and agribusiness tourism. The variety of living environments in the Bandung area does not only consist of urban areas, but also sub-urban areas, and also rural areas in

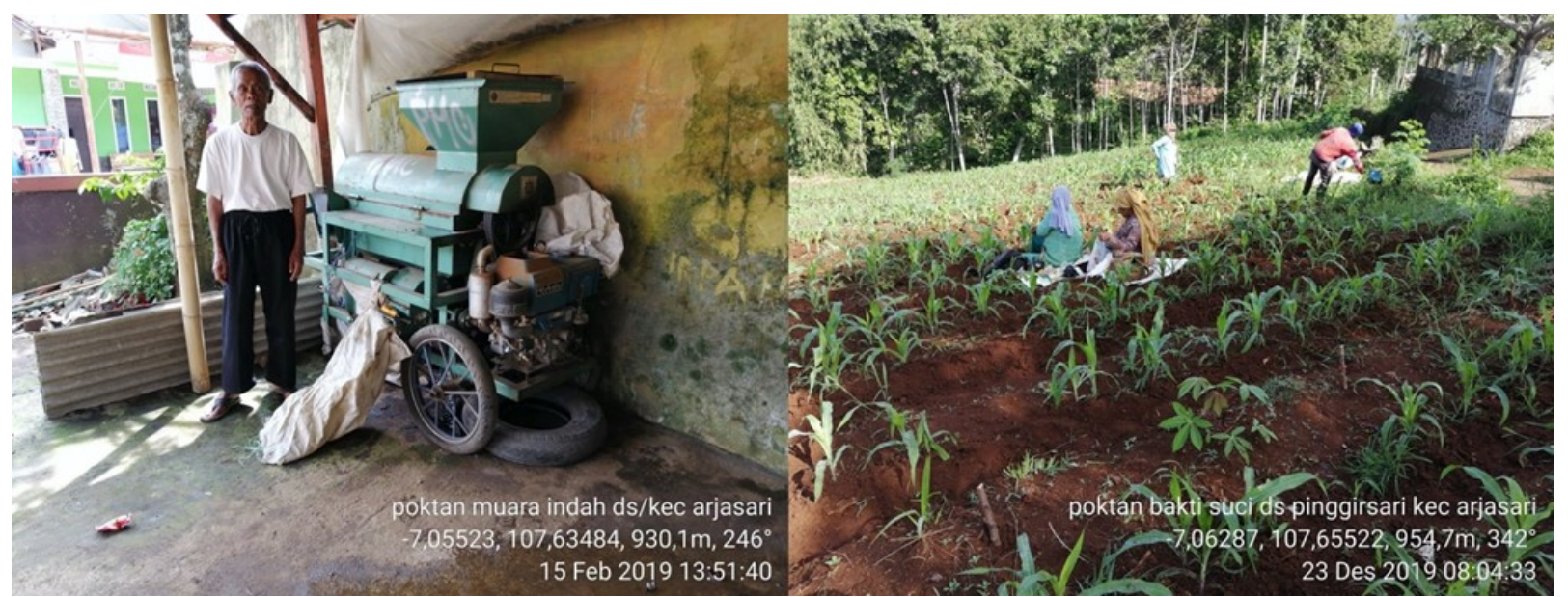

Figure 2. Corn Farmers and Corn Processing Equipment in Arjasari Source: Mr. Dais, Secretary of Arjasari Village 
Tabel 2. Demographic Data of Arjasari Village Communities (By Occupation)

\begin{tabular}{clc}
\hline No & \multicolumn{1}{c}{ Occupation } & Total \\
\hline 1 & Unemployment & 2662 \\
2 & Taking care of household & 2158 \\
3 & Student & 237 \\
4 & Pensionary & 46 \\
5 & Civil Servants (PNS) & 36 \\
6 & Indonesian National Army (TNI) & 2 \\
7 & Indonesian Police (POLRI) & 1 \\
8 & Trading & 51 \\
9 & Crop Farmers & 151 \\
10 & Livestock Farmers & 4 \\
\hline
\end{tabular}

Source: Secondary Data (Processed)

the form of hilly slopes and rice fields. The spirit of art in Bandung society is strongly reflected in various types of tourism that rely on natural beauty. In addition to seeking taste satisfaction, tourists visiting Bandung also aim to obtain inner satisfaction, either through natural recreation, or a booming business, such natural resource-based photo spots, that are packed with a variety of interesting tricks and architecture.

The passion of Bandung people as creative ans artistic people give a great opportunity for the development of the creative sector (Achwan, 2014). It can also be applied to the agribusiness sector in Arjasari Village, that is mostly a rice field area. With the application of creativity in the agricultural sector, corn farmers can have various alternatives to change the form of harvested corn into several variants of processed maize/corn products. Thus, it can employe people who do not have a job and it can increase the economic productivity of Arjasari Village from corn agricultural products, it can minimize farmers' loss because it is purchased cheaply by middlemen (Djali et al., 2018). The potential of corn agribusiness can also be directed into the potential for agribusiness on a large scale, and the potential for agrotourism to create a corn plant education area that can support local peoples of Arjasari Village who have already understood about corn agribusiness, with an educational model.

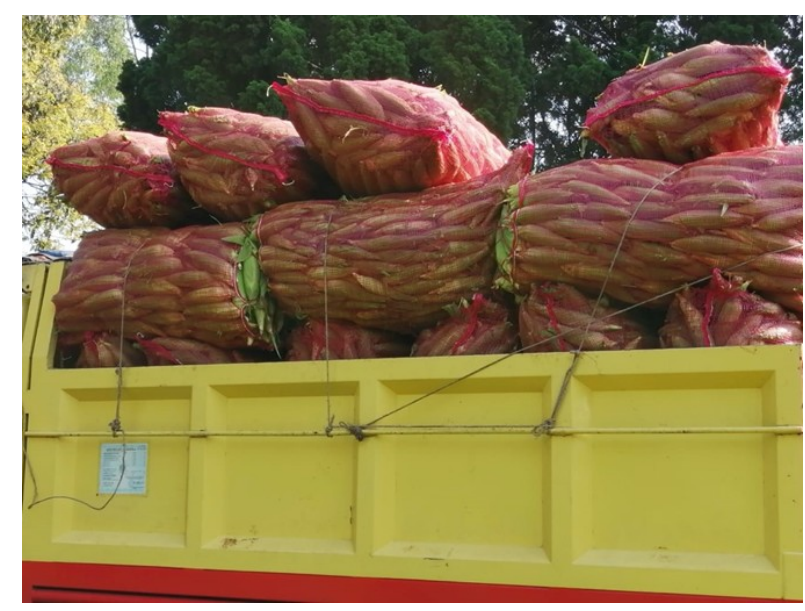

Figure 3. Distribution of Corn Harvest

Source: Mr. Dais, Secretary of Arjasari Village

\section{Potential}

Cultural potential in an area can be an investment value, a form of commodities in the economic sector, the elements of identity forming in a certain area, and potential in the tourism aspect (Januarti and Wempi, 2019). In the potential aspect, the index of a city can be illustrated from the supporting aspects of the city that have the potential to be developed and become one of the selling points for potential tourists and/or investors who will consider Bandung as one of the destinations for tourism or business (Larasati and Nazaruddin, 2016). Bandung that is supported by satellite areas certainly provides opportunities and contributions for potential tourists either for traveling or doing business in the Bandung area. Aspects that can be developed in Bandung are tourism and 
agribusiness or business in agriculture (Puspitasari, 2011). It is because the city center of Bandung is already busy that is marked by increasingly severe congestion. Thus, the local government must mobilize the interest of tourists who come to the city to be decentralized, so the focus of visitor attention is not centered on urban Bandung, but also on existing supporting areas. around Bandung. Exploiting the potential of an area is an attraction for newcomers and prospective business people who will invest in the area (Briciu et al., 2020). Agribusiness is a big opportunity in Bandung because the area of rice fields in Bandung Regency in 2016 was 35,478 hectares or about $20.13 \%$, and dry land covering an area of 140,705 or around $79.84 \%$ hectares. They are mostly dominated by dry land for agriculture. This is a positive signal for the development of the Agribusiness aspect in the Bandung area because there is still a lot of land that can be planted by farmers.

Arjasari as one of corn producer villages in Bandung has a highly potential to contribute in progress of the Bandung area through the agribusiness aspect, considering that the Arjasari area grows various types of plants, starting from rice, sweet potatoes, cassava, and corn (Dini et al., 2018). If it is seen the data on demand and availability of corn nationally, the availability of maize/corn in Indonesia is already a surplus. However, the import policy is still enforced to maintain the price of the national maize, and aspects of the bilateral relationship between countries. Corn can be converted into other forms of flour, milk, ice cream, rice, snacks, chips, and other types. On the Instagram site, corn can also be processed into cakes which have a selling value because of their uniqueness and interesting taste.

Therefore, With the abundant availability of corn, farmers should be encouraged to modify the yield of corn to not only sell it cheaply because of the abundant maize reserves, but to convert its use value into various other variants in order to increase income and competitiveness for Arjasari farmers. To support the government's program to create an independent and competitive economic structure (Umasugi, 2012), the local government must create a program that can accommodate the vision and mission of the central government by educating Arjasari farmers so they can have broader insights about output products from planted corn. Thus, they can compete and increase their selling value and income independently. The potential for maize/corn, which continues to increase from year to year, encourages the government to be able to continue to maintain the value of the corn harvest by providing corn seeds and agricultural tools to farmers. Thus, the price of corn remains stable and farmers are not disadvantaged. With adequate maize prices, farmers will be motivated to be able to apply technology in their agriculture. In the process of maximizing the productivity of agricultural products, capital, labor factors, agricultural equipment, technology and land are closely related. Therefore, the supporting factor must be taken into account efficiently, so that the profit can be maximized (Deviani et al., 2019).

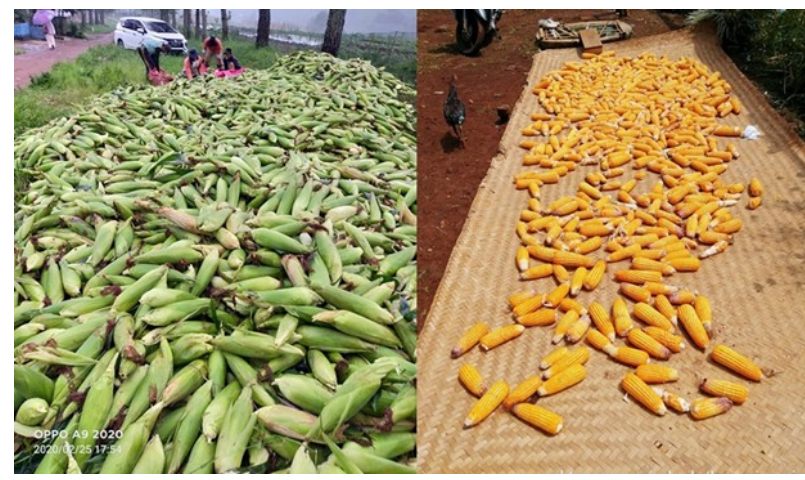

Figure 4. Corn Harvest

Source: Mr. Dais, Secretary of Arjasari Village

\section{Prerequisites}

A good area does not only have aspects of location, population, enthusiasm, potential, and existence of the area, but also how the supporting factors can be a important for the stability of the area. The progress of a good city can't be separated from the development of good infrastructure (Sumaryoto, 2010). Various factors that support the existence of a city can include the 
transportation system, government system, security factors, how public acceptance of the area, holding activities that respond to community needs, and other facilities.

City Brand plays an important role in the success of a city because by good method, City Brand is able to introduce a city or area that is not yet known by the general public. In a brand, the image is an image or perception from consumers to the association attached to a brand, then in the city scope the image of a city can provide associations to potential visitors or tourists, even investors who want to consider the destination (Fensi \& Christian, 2018). A city brand can also improve the image of the city if it is still not optimal. It can also attract foreign and domestic migrants, as well as attract investors to conduct business and investment transactions in the area, and increase trade volume (Saputra, 2016). In its application in the city of Bandung, especially Arjasari Village, the six components of the City Brand are very important to note because they can advance the economy and the development of the creative industry, especially in agricultural sector. With various aspects of forming a city brand including people, pulse, place, potential, prerequisites, and presence, it can be seen that the superior points are the strengths of Arjasari Village to be developed and applied in the agribusiness sector to be able to improve the economy and social conditions of the people of the Arjasari Village area.

The potential of Arjasari Village that can result 1.5 million tons or sweet corns/hectare absolutely gives a new focus point for the local government to be developed and effective for economic development, especially the people of Bandung in the Arjasari Village area. Corn as a potential element in Arjasari Village provides an overview of business opportunities and projections for the area to develop in the future. The great potential in the area must be managed properly, one of which can be through Agro-education tourism which is also part of Agribusiness, and widely influences the socio-economic conditions of the people of Arjasari Village and can advance the area through potential aspects in city brand studies. Agricultural education can be in the form of knowledge and training programs as well as field trips regarding technical planting to outputs in the form of various processed corn products as agricultural products from Arjasari Village.

Bandung as tourism destination shows that presence aspect and its existence can't be worried. Yet, the local government must pay attention to areas that support Bandung such as Arjasari Villageby publication and media exposure to the area. When referring to the prerequisites aspect, Arjasari has not met the criteria in that aspect, especially if the government is targeting to bring in local and foreign tourists. Another thing that local governments can do is by collaborating with companies that use corn as the main raw material in their production process, which can be applied to the Corporate Social Responsibility (CSR) system which must be carried out by all companies managing natural resources (Fernando and Marta, 2018). The local government must prepare adequate infrastructure and be balanced with lodging facilities around the Arjasari area. On the place factor, Arjasari has a large rice field location, and a location not far from the city of Bandung can make it easier for potential tourists and investors to visit Arjasari. The potential of corn agribusiness in the area must also be monitored by the local government. Thus, Arjasari Village meets the potential criteria.

\section{Presence}

This point depicts the existence of image, status and position of a city in national and international levels. This can be proven by people's awareness of the existence of the name of a city in a country. In addition, it is also seen how the contribution of the city to the world in aspects of culture, science, or the government system in a certain period of time. 
Table 3. Best City Ranking

\begin{tabular}{clc}
\hline No & \multicolumn{1}{c}{ City } & Total Index \\
\hline 1 & Bandung & 90.19 \\
2 & Surabaya & 88.08 \\
3 & Semarang & 86.95 \\
4 & Medan & 85.46 \\
5 & Malang & 84.71 \\
\hline
\end{tabular}

Source: Secondary Data (Processed)

The data on the ranking of the existence of a city reflected in the index value is based on the attractiveness of an area that aims to increase investment, the targeted strategy the government will undertake as well as information on potential investment in Indonesia. With the success of Bandung as a leader in the best city category, there are opportunities for potential investors to give a sense of confidence in investing in Bandung.

If the image of Bandung can be understood correctly, then the equity of the brand can only increase (Hankinson, 2004). Therefore, the image forming components based on the city brand component, especially presence, must be managed properly.

\section{Place}

This points explains physical aspects of a city that can also shape the perceptions and opinions of tourists or potential tourists to be able to visit the area. Things that can be illustrated from this point include how the atmosphere in the city, the beauty of the city, and the climate (Hambalah, 2017). Bandung has a strategic position because it is connected to various cities and regions (Angestiwi and Rakhmatulloh, 2013) either by land or by air. Access to this city is also fairly easy because there are various choices of transportation modes ranging from buses, trains and even expressways. The government also supports the development of the city of Bandung by planning the construction of the Jakarta Bandung Fast Train that will be completed in 2021. This will certainly open up opportunities for Bandung to become an increasingly advanced city and has the potential to be developed in the superior aspects that exist in Bandung such as tourism, its natural charm. beautiful, and is supported by a smart city system built in the city of Bandung and has received a positive response to improve order and a sense of security for the community or tourists who come to Bandung City (Insani, 2017). With a cool climate at night, it certainly adds to the comfort of being able to stop and spend the night here. Arjasari as in Bandung Regency is 1 of 11 villages in Arjasari District that is at an altitude of 700-1000 meters above sea level. With an area of 768,848 hectares of rice fields, this village is very suitable to be developed into an agribusiness village (Wicaksono et al., 2018). A very big opportunity is seen from the vast area of rice fields that can then be developed into a corn education area in the Arjasari village as one of the selling points for the area. It is very possible to do this considering that farmers in Arjasari already understand the ins and outs of growing corn with self-taught skills and education that cannot be underestimated.

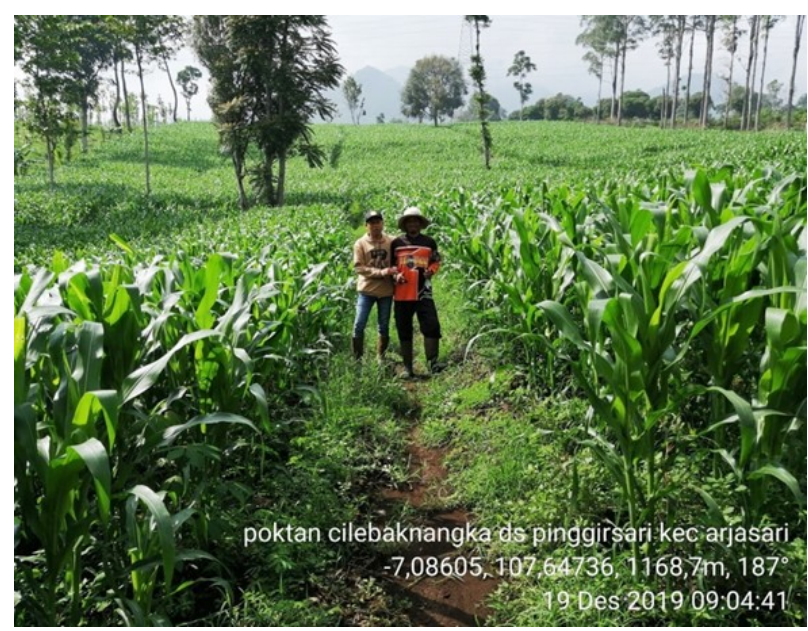

Figure 5. Corn Farmers and Corn Fields in Arjasari

Source: Mr. Dais, Secretary of Arjasari Village

\section{CONCLUSIONS}

Based on employment data in aspect of people in Arjasari Village, it shows high numbers of unemployed people of Arjasari Villagers due to lack of education, knowledge. Their ability to develop Arjasari Village is also an obstacle. In addition, 
villagers of Arjasari who have completed further education in lectures in the field of agriculture or are experts in agricultural can become communicators for residents to provide education related to the potential of the village according to their area of expertise, because a communicator has greater influence. The marketing communication aspect is also important to form an image about Arjasari Village. Thus, the potential tourists can remember and arise an interest in visiting Arjasari Village. Therefore, government officials in Arjasari Village need to pay attention to promotion and exposure to Arjasari Village in the world of social media that can be conducted through advertisements or other explanatory media to create positive word of mouth for Arjasari Village and to motivate tourist to visit Arjasari Village.

The crop yield of corn as a potential aspect in Arjasari Village also opens up opportunities to make this commodity a new form of agriculture, such as agricultural education. In agro-education, an area can introduce corn processing techniques, capabilities, and processes, and even show the creativity of the local population with processed corn products that can be a selling point for farmers in Arjasari Village. It can socially impact and drive their economy that can also be referred to as Agrosocionomics. The pulse aspect must also be developed, maintained and transmitted to the people in Arjasari Village. Thus, they understand the great potential in the corn agribusiness that they live every day has a great opportunity to be expanded into other business fields with corn-based ingredients and will definitely make a breakthrough both in the creative industry, employment opportunities, even in the economic sector to advance the welfare of the Arjasari people and avoid being dominated by middlemen who seek profit behind the labors of corn farmers in Arjasari Village. Researchers provided research recommendations for the local government to maximize the potential of Arjasari Village by building existing human resources, and providing information through marketing the area to the community in general and exploring the individual potential of farmers in Arjasari Village with an integrated strategy.

\section{REFERENCES}

Achwan, R. 2014. Dua dunia seni: industri kreatif fesyen di Bandung dan Bali. Masyarakat: Jurnal Sosiologi 19(1): 57-75.

https://doi.org/10.7454/mjs.v19i1.4696

Alperytè, I., and M. Išoraitè. 2020. Developing a city brand. Journal of Intercultural Management 11(4): 1-27. https://doi.org/10.2478/joim-2019$\underline{0022}$

Angestiwi, T., and A. R. Rakhmatulloh. 2013. Analisis kinerja terminal leuwipanjang terhadap pergerakan Kota Bandung. Jurnal Pembangunan Wilayah \& Kota 9(2):

205.

https://doi.org/10.14710/pwk.v9i2.653 $\underline{7}$

Azmie, U., R. K. Dewi, and I. D. G. R. Sarjana. 2017. Pola kemitraan agribisnis tebu di Kecamatan Jetis Kabupaten Mojokerto. Agrisocionomics: Jurnal Sosial Ekonomi Dan Kebijakan Pertanian 6(1):

https://doi.org/http://dx.doi.org/10.211 07/agriekonomika.v6i1.1895

Briciu, V. A., C. I. Rezeanu, and A. Briciu. 2020. Online place branding: Is geography 'destiny' in a 'space of flows' world?. Sustainability 12(10): 4073.

https://doi.org/10.3390/su12104073

Deviani, F., D. Rochdiani, and B. R. Saefudin. 2019. Analisis faktor-faktor yang mempengaruhi produksi usahatani buncis di Gabungan Kelompok Tani Lembang Agri Kabupaten Bandung Barat. Agrisocionomics: Jurnal Sosial Ekonomi dan Kebijakan Pertanian 
3(2):

165-173.

https://doi.org/10.14710/agrisocionomi cs.v3i2.6099

Dini, A. Z., Y. Yuwariah, F. Y. Wicaksono, and D. Ruswandi. 2018. Pertumbuhan dan hasil tanaman jagung (Zea mays L.) pada pola tanam tumpangsari dengan ubi jalar (Ipomoea batatas (L.) Lam) di Arjasari Kabupaten Bandung. Jurnal Agrotek Indonesia 3(2): 113120.

\section{https://doi.org/10.33661/jai.v3i2.1375}

Djali, M., I. L. Kayaputri, and D. Kurniati. 2018. Teknologi pengolahan emping jubika sebagai upaya peningkatan nilai guna jagung manis di Desa Arjasari Kabupaten Bandung. Jurnal Pengabdian Kepada Masyarakat 2(1): 19-22.

https://doi.org/10.24198/dharmakarya. v7i3.14594

Fadhilah, M. L., B. T. Eddy, and S. Gayatri. 2018. Pengaruh tingkat pengetahuan, sikap dan keterampilan penerapan sistem agribisnis terhadap produksi pada petani padi di Kecamatan Cimanggu Kabupaten Cilacap. Agrisocionomics: Jurnal Sosial Ekonomi Pertanian 2(1): 3949. https://doi.org/10.14710/agrisocion omics.v2i1.1327

Fensi, F., and M. Christian. 2018. Determinan citra merek pada iklan produk gawai "Vivo" berdasarkan aspek "celebrity endorser". Bricolage : Jurnal Magister Ilmu Komunikasi 4(2): 163-179. https://doi.org/2615-6423

Fernando, J., and R. F. Marta. 2018. Nasionalisme fashion dan pemantik citra negara dalam situs www.damniloveindonesia.com.

National Conference of Creative Industry: 870-881. https://doi.org/10.30813/ncci.v0i0.129 $\underline{9}$
Hambalah, F. 2017. Surabaya sebagai kota maritim: strategi pemasaran city branding dan tantangan di masa depan. Jurnal Aplikasi Administrasi 20(1): 6169.

Hankinson, G. 2004. The brand images of tourism destinations: a study of the saliency of organic images. Journal of Product \& Brand Management 13(1): 6-14.

https://doi.org/10.1108/106104204105 $\underline{23803}$

Insani, P. A. 2017. Mewujudkan kota responsif melalui smart city. Publisia: Jurnal Ilmu Administrasi Publik 2(1): 25-31. https://doi.org/10.26905/pjiap.v2i1.142 $\underline{3}$

Januarti and J. A. Wempi. 2019. Makna tenun ikat Dayak Sintang ditinjau dari teori semiotika sosial Theo Van Leeuwen. Bricolage: Jurnal Magister Ilmu Komunikasi 5(1): 73-90. Retrieved from

https://journal.ubm.ac.id/index.php/bri colage/article/view/1743/1465

Larasati, D., and M. Nazaruddin. 2016. Potensi wisata dalam pembentukan city branding Kota Pekanbaru. Jurnal Komunikasi 10(2): 99-116. https://doi.org/10.20885/komunikasi.v ol10.iss2.art1

Luthfi, A., and A. I. Widyaningrat. 2013. Konsep city branding sebuah pendekatan "the city brand hexagon" pada pembentukan identitas kota. Seminar Nasional Manajemen dan Bisnis Ke-3: 315-323.

Puspitasari, S. 2011. Potensi wisata agro Kabupaten Bandung berdasarkan aspek permintaan dan penawaran. Journal of Regional and City Planning 22(1): 33-48. Retrieved from http://journals.itb.ac.id/index.php/jpwk /article/view/4132 
Revania, L. 2013. Analisis faktor-faktor yang mempengaruhi impor jagung di Indonesia Tahun 1982 - 2012. Jejak: Journal of Economics and Policy 7(1): 102-112.

https://doi.org/10.15294/jejak.v7i1.384 7

Saputra, E. 2016. Komunikasi dan informatika dalam mengelola "branding" Kota Samarinda. EJournal Ilmu Komunikasi 4(2): 321-335.

Sukmadewi, R., and N. J. A. Novel. 2019. Analisis relevansi city branding Kota Bandung melalui pendekatan nilai indeks kebahagiaan. Responsi: Jurnal Pemikiran dan Penelitian Administrasi, Sosial, Humaniora, dan Kebijakan Publik 2(3): 83-93.

Sumaryoto. 2010. Dampak keberadaan jalan tol terhadap kondisi fisik, sosial, dan ekonomi lingkungannya. Journal of Rural and Development 1(2): 161-168.

Umasugi, L. 2012. Daya saing di Kota Ternate. Agrikan: Jurnal Agribisnis Perikanan 5(1): 44-48. https://doi.org/10.29239/j.agrikan.5.1.4 $\underline{4-48}$

Utama, I. G. B. R. 2016. Keunikan budaya dan keindahan alam sebagai citra destinasi Bali menurut wisatawan australia lanjut usia. Jurnal Kajian Bali 6(1):

149-172. https://doi.org/10.2139/ssrn.2790503

Wahyuningsih, A., B. M. Setiyawan, and B. A. Kristanto. 2018. Efisiensi ekonomi penggunaan faktor-faktor produksi, pendapatan usahatani jagung hibrida dan jagung lokal di Kecamatan Kemusuk, Kabupaten Boyolali. Agrisocionomics: Jurnal Sosial Ekonomi Pertanian 2(1): 1-13. https://doi.org/10.14710/agrisocionomi cs.v2i1.2672

Wicaksono, F. Y., Y. Maxiselly, T. Nurmala, P. U. Suherman, A. Fauzan, and A. M.
Nurdin. 2018. Respons masyarakat terhadap pengenalan tanaman gandum dan produk-produknya di Desa Arjasari Kecamatan Arjasari Kabupaten Bandung. Dharmakarya: Jurnal Aplikasi Ipteks untuk Masyarakat 7(1): 32-37. https://doi.org/10.24198/dharmakarya. $\underline{\mathrm{v} 7 \mathrm{i} 1.14740}$

Yurisma, D. Y., E. B. W. Agung, and A. Sachari. 2015. Kesenian tradisi reog sebagai pembentuk citra Ponorogo. Visualita $\quad 7(1)$ : $1-15$. https://doi.org/10.33375/vslt.v7i1.1081 